\title{
Trauma in Toni Morrison's Novel God Help the Child
}

\author{
Roz Salahuddin Ahmed', Sherzad Shafi' Babo ${ }^{2}$ \\ Department of English, College of Languages, Sallahaddin University
}

\section{Article Info}

Received: July, 2019

Revised:August,2019

Accepted:August,2019

\section{Keywords}

Trauma, trauma theory, racial trauma, colorism, parental trauma.

\section{Corresponding Author}

rozhmezhoo99@gmail.com

\begin{abstract}
Trauma can be experienced in life due to many adverse situations that encounter the modern man. Due to the prevalence of trauma in the lives of individuals and communities, Trauma as a theory and discipline was conceptualized in the 1990s. Traumatic incidents can be recognized in Toni Morrison's novel God Help the Child which include many types of traumas such as racial trauma including colorism and parental trauma. Characters in the novel are affected by traumas that cause unfavorable consequences. The protagonist Lula Ann, despite going through the harmful effects of trauma, she creates a new identity which is devoid of racist views. This paper aims to present the traumatic situations experienced especially by the protagonist in the novel, its implications and the transformation that the protagonist reaches.
\end{abstract}

\section{Introduction}

Many psychological associations and theorists define trauma as serious harm that affects human beings negatively and leaves its toll on their bodies and psyches. The American Psychiatric Association[APA] (2000) defines trauma as: direct personal experience of an event that involves actual or threatened death or serious injury, or other threat to one's physical integrity; or witnessing an event that involves death, injury, or a threat to the physical integrity of another person; or learning about unexpected or violent death, serious harm, or threat of death or injury experienced by a family member or other close associate. The person's response to the event must involve intense fear, helplessness, or horror (or in children, the response must involve disorganized or agitated behavior (p.463).

Trauma emerged to be studied as a psychological disorder only in the later twentieth century, though its early signs and formation was recognized in the 1800s. Leys (2010) states that the earliest discussion of trauma as an isolated disorder began in the 1860s through the works of John Erichsen(1866) who studied the consequences of fear on people who in railway accidents.

The field of dynamic psychiatry was first investigated by Janet (1892) and then Freud and 
Breuer (1093-1895) who published studies about the dynamics of hysteria. Janet is accountable for the positive characterization of hysteria. Later Freud in 1893 developed his posttraumatic model to cover all hysterical symptoms. Both Freud and Janet acknowledged the contribution of biological and social elements in the formation of hysterical symptoms but only Janet (1892) emphasized each of the biological, psychological and social factors that affects each person. Freud's Psychological models remained illness related. By contrast, Janet developed a health focused model based on growth and maintenance of the self. This was founded on the analysis of personality based on memory and other percepts.

Herman (1992) clarified that Freud first claimed that hysteria affects women due to sexual abuse when he conducted his hypnotic studies and it is the main cause of trauma but later he abandoned this conviction in fear of the clash between him and the patriarchal society which was and still is in control. Freud (1952) constituted his theories that are related to the unconscious mind and the unconscious fantasies to explain psychological phenomena. In the wake of the two World wars and the Holocaust in addition to the emergence of feminism in the 1970s due to increased maltreatment of women and domestic violence, the field of trauma studies started to emerge reaching its full formation and recognition starting from the year 1990 .

Kolk (2014) reveals reports that 12 million women were victimized by rape in the United States in 2014 alone. He further clarifies that fifty percent of those women were under the age of fifteen at the time of assault. He expounds a survey that reveals that every year there are three million cases of child abuse. Kolk clarifies that children affected by trauma will probably be affected by its negative consequences even in adulthood. Kolk demonstrates that traumatic memories are vivid, unchanging and easily triggered which creates difficulties for the traumatized in order to continue functioning in life Cathy Caruth (1996) offers an extensive study of trauma narratives by analyzing them according to trauma theory and psychoanalysis. Caruth further poses the question of whether trauma is a form of death or survival. She concludes that trauma is a form of death and then of survival which is elucidated by the intersection that happens between the language of literature and psychoanalytic theory. Caruth continues to reinterpret Freud's writing on trauma. She illustrates that the language of trauma is literary because it challenges our understanding. Caruth presents Freud's theory of latency which refers to the reoccurring of traumatic experience, a reliving of the traumatic experience because during latency traumatic symptoms are not apparent and this causes the repetition of the traumatic experience. These notions about trauma are the basis of the emergence of trauma as a theory and a literary discipline which makes authors like Toni Morrison portray traumatic aspects in their novels. Toni Morrisons's novel God Help the Child is presented with reference to her fiction and the traumatic events that encounter her protagonist in the novel.

\section{Toni Morrison's Fiction and Racial Trauma}

Toni Morrison is known for a unique style of writing, that is why her writing style is investigated by many scholars to reveal her special interests and areas of focus in writing. Yoshinobu (2001) states that Toni Morrison's aim is to make a literature that is both beautiful and political also at the same time. Morrison's writing is centered around the dilemma's between narrative based on history and narrative based on myth particularly Black history and Black myth. Morrison investigates Western myths related to religion, politics and legal discourse with some shades of magical realism which addresses the imperialistic and malecentered discourse.

Morrison presents the difficult traumatic past of African Americans but she insists that the traumatic past presented is necessary through representing the complexity of traumatic past. In an interview for The Paris Review magazine, Elissa Schappell (1992) asks Morrison about how the black writers are recognized in a world which is dominated by white standards. Morrison states that she plays with the language written by opening it up. She says that she wrote a story entitled Recitatif in which there are two little girls who are orphans, one white and one 
black. But she does not inform the reader who is black and who is white. She asserts that she prefers to use class codes instead of racial codes. Duvall(2000) asserts that Morrison employs DuBois theory of Double Consciousness which he believes affects African Americans. Schappell (1992) states that Morrison is known for her mastery of public novel investigating the relationships between the races and sexes and the push and pull between civilization and nature. Additionally, Morrison focuses on combining myth and the fantastic with a deep political allegiance to her community and its crisis.

Morrison's own childhood experiences allowed her to be an advocate for protecting children. In an interview with Terry Gross for Fresh Air radio station (2015), she narrates the story of how her father protected her from a white man by throwing him down stairs thinking he was after his daughters and how she felt safe and protected:

I think his[Morrison's father] own experience in Georgia would have made him think that any white man bumbling up the stairs toward our apartment was not there for any good. And since we were little girls, he assumed that. I think he made a mistake. I mean, I really think the man was drunk. I don't think he was really trailing us. But the interesting thing was- he survived. B, the real thing for me was I thought- I felt profoundly protected and defended [...]. So I didn't think of it as, oh, look, my father's a violent man. He never, you know, spanked us. $\mathrm{He}$ never quarreled with us. He never argued with us. He was dedicated, and he was sweet. So he did this thing to protect his children.

Morrison in an interview with Carol Off (2015) for As It Happens Canadian show says "In this book, I [Morrison] was very interested in childhood trauma paralyzing us in the contemporary world". However, Morrison also shows the possibilities of healing from horrors of the past. She presents how her characters are enabled to face their pain and suffering and reclaim their lives. Ramirez (2017) states that in God Help the child is a tale that is exposing childhood abuse and trauma but it is also a tale of healing and hope.

Toni Morrison in her novel God Help the Child (2015) addresses the double standards that
African Americans adopt. The notion of "Double Consciousness" founded by DuBois (1903) in "The Souls of Black Folk" is considered a symptom of racial trauma which is also used by George Yancy (2008) who states that the white gaze is often is apprehended by exposing the eurocentric cultural perspective which is regarded a narrow perspective based on the European perspective which marginalizes the African American identity and omits the African American authorial space. The eurocentric white gaze leads to the objectification of African Americans instead of considering them as independent subjects. This gaze forces African Americans to view themselves out of themselves devoid of a sense of identity according to the perspective of the white world. Stayton (2017) states that these notions and struggles of the African American identity can be recognized clearly in Toni Morrison's novel God Help the Child. Morrison unveils the traumatic struggles of African Americans with historical and narratological context Stamm (1996) states that the cultural or racial trauma is considered to be more than physical harm of people, property and landscape such as what is seen in warfare. This type of trauma is directly or indirectly is an attack to lots of foundations that constitutes human dignity and societal/ethnic identity such as body/ space practices, history, language, religion and state and economics. Equiano (1814) narrates the facts during the journey across the Atlantic ocean which states that those Africans who survived the passage to America often considered themselves as motherless children being traumatized Africans who were confined with shackles and cuffs and they were bought and sold away. They were taken away from their communities and devalued. This traumatizing of the children of Africa would leave a deep wounding that lasts for generations. Collins (1991) states that black mothers, under the slave system, experienced excruciating painful time. The suffering they have gone through, made them not to raise up their children as usual but instead it let them accomplish infanticide. Black mothers and daughters face an unusual circumstance due to slavery and its aftermath -Black daughters raised by mothers are affected by the hostile environment and have to 
be in constant wavering between their feelings about the difference between the idealized versions of maternal love extant in popular culture and the strict and often troubled mothers in their lives. Sweetness suffers from the emotional burden of her husband's withdrawal from raising his daughter after her birth. Adrienne Rich (1976) in her analysis of the dilemma of the mother who brings up her children without support from their father, argues as follows:

The black mother has been charged by both white and black males with the - castrationll of her sons through her so-called matriarchal domination of the family, as breadwinner, decision-maker, and rearer of children in one. Needless to say, her - power\| as - matriarch\| is drastically limited by the bonds of racism, sexism, and poverty. What is misread as power here is really survival-strength, guts, the determination that her children's lives shall come to something even if it means driving them, or sacrificing her own pride in order to feed and clothe them (p. 204).

Morrison clearly shows the effects of race based trauma which hits the core of the African American identity. The effects of communal or racial trauma disables the formation of black identity. Identity formation is constituted through creating a unity between the self and the community because the self is constructed within the community. This is shown in W.E. B DuBois's text (1903) when he explains the internal conflict the African American individual feels, he says: "It is peculiar sensation, this double consciousness, this sense of always looking at one's self through the eyes of others, of measuring one's soul by the tape of a world that looks on in amused contempt and pity" (p.45).

Kai Erickson(1995) in her acclaimed work Everything in Its Path makes a distinction between individual trauma and communal trauma clear. She states: "By individual trauma, I mean a blow to the psyche that breaks through one's defenses so suddenly and with such brutal force that one cannot react to it effectively... By collective trauma, on the other hand, I mean a blow to the basic tissue of social life that damages the bonds attaching people together and impairs the prevailing sense of community" (p.153).

New Historicism is a key theoretical perspective coined in the 1970s which is pluralistic in its application and questions the assumed notion that history and historical narratives are all objective . Prior to New Historicism, Historical theory was prevalent that assumed that historical record and narratives are objective in nature. This contradiction in beliefs about history paves the ways for new possibilities and interpretations proposed by authors (Stayton, 2017).

D.G. Myers (1989) clarifies the major premises of New Historicism as a theory:

The proper way to understand it [New Historicism], therefore, is through the culture and society that produced it. (2) Literature, then, is not a distinct category of human activity. It must be assimilated to history, which means a particular vision of history. (3) Like works of literature, man himself is a social construct, the sloppy composition of social and political forces- there is no such thing as a human nature that transcends history. Renaissance man belongs inescapably and irretrievably to the Renaissance. There is no continuity between him and us; history is a series 'ruptures' between ages and men. As a consequence, the historian/critic is trapped in his own 'historicity' (p.3-4).

Toni Morrison as a literary scholar uses the New Historicism theory to for creating new histories of the marginalized people of her race that shapes and reshapes the human experience and by historically placing voiceless people at the center of her narratives. She allows for openended interpretations of her literature. Morrison believes that literary works are the product of time but also at the same time literary works create ideologies. In reshaping history, Morrison attempts to urge African Americans to move beyond their past traumatic experiences. Morrison is interested in rememory which means the ability to tell and retell history from a human perspective. Goulimari (2011) states that Morrison might be considered subjective in her writings. However, Morrison does not intend to offer an objective view of the past through her writings, instead she favors a subjective view that match the literary school of New 
Historicism which favors the effective portrayal of histories instead of the objective portrayal.

\section{Femininity and the Social Stigma of Ugliness}

In her novel God Help the Child (2014) Morrison aims to present the black female experience within a white-dominated society and specifies the ways in which the identity of African American girls is affected by the prevailing cultural standards. As Cynthia Davis(1999) mentions all of 'Morrison's characters exist in a world defined by its blackness and by the surrounding white society that both violates it and denies it" (p.7). The destructive manifestations of racial oppression in Morrison's fiction underline the turbulence that African Americans experience. Being aware of the repeated pattern of discrimination, Morrison (2000) claims that ' $[t]$ he Look of white society [...] not only freezes the black individual but also classifies all blacks as alike' (p.10). Her African American characters, who have difficulty identifying themselves as members of the black community or have adopted white cultural standards, are fragile individuals struggling with self-definition and self-worth.

In God Help the Child (2015), Morrison emphasizes the usage of black beauty so that it becomes a profitable commodity for the cosmetics business and the fashion industry. Fragkouli (2017) states that Lula Ann (the protagonist), Aims to fit in the ideal image of exotic dark-skinned feminine. Lula Ann gets overly excited by the stereotypical portrayal of the luscious, curvy, and sensual black woman of the 1990s. Fragkouli (2017) states that Bride depends on her outward appearance and on her dark skin in order to be accepted as a respected member of the beauty industry. The novel highlights the pervasive effect of the established western beauty standards on the African American community in general and on black mothers and on vulnerable young black girls specifically. While growing up in the governance of the dominant white culture, black-skinned girls are bruised not only by the opinions and conducts of the whites but also by the opinions and attitudes of their own mothers.
Massey and Denton (1993) state that Morrison's God Help the Child (2015) narrates the realities of contemporary America (from the 1990s to the first decade of the 21st century) and investigates whether the black female condition has improved. Aside from the fact that "skin color remains a powerful basis of stratification in the United States" ( p.85), Morrison displays that gender can stimulate prevalent discrimination when it is afflicted with the sexist images of white supremacy. According to Robyn Wiegman(1995), Morrison depicts the ways "the social violences of race and gender" (p.1) influence the life and psychology of African American females. "America's quite violent and damaging historical exclusions" (Wiegman,1995: p.9) and social inequality are exposed. Morrison's fictional dark-skinned girls and women are dealt with as subhuman, and/or are treated as sex objects and male possessions. Davis (1999) states that considering "[w]omanhood, like blackness, is Other in this society, and the dilemma of woman in a patriarchal society is parallel to that of blacks in a racist one" ( p.12), Morrison's protagonists are twice victimized by sexist stereotypes because they are women and racist views because they are black skinned. Contextualizing Morrison's contribution with regards to the position of the African American women and the impact of white American culture on the black community, it is necessary to examine the literary objectives of black women novelists in terms of race and gender. African American female scholars, including Morrison, feel the urgency to break the silence and make black voices powerfully recognized and heard by the general public, especially by white American society. As Morrison explains in her essay, "Unspeakable Things Unspoken" (n.d.) that despite the fact that African American artists have been acknowledged and serious scholarship "has moved from silencing the witnesses and erasing their meaningful place in and contribution to American culture" (p.31) African American literature is frequently regarded as inferior, "imitative, excessive, sensational, mimetic (merely), and unintellectual" (p.32). There are still stereotypical and minimizing representations of the literature created by African Americans even in contemporary white 
aesthetics that seek to obscure the voice of the black race, keep its advancements hidden, and send blacks to the social margins. Despite the efforts of white racists to keep the system of racial segregation active, things began to change gradually in American society during the postwar decades. Missy Dehn Kubitschek(1998) emphasizes that "America's social landscape changed substantially from 1950 to 1970 " (p.28) with the emergence of the Black Power movement, the feminist movement, the civil rights movement, and the "Black is Beautiful" campaign. A vital part of the black freedom struggle of the 1960s were African American writers and artists who worked to change the ways black Americans were represented in literature and the arts. This movement is known as the Black Arts movement. According to Elliott Butler-Evans (1989) states the black aesthetic was created to 'represent [b]lack life as lived by the [b]lack masses, to fashion identities that corresponded with those of ordinary [b]lack people, and to displace Western cultural hegemony' (p.21). Butler-Evans (1989) states that regarding Morrison's literary works, it has been said that the author uses fiction "as an instrument of empowerment" (p.7). To be more precise, Kubischek (1998) states that Morrison's novels are inseparable from "the Black Arts and feminist protests against racist and sexist injustice" (p. 30). In fact, Morrison exposes race and gender as the powerful tools with which white America suppresses and discriminates African American girls and women.

In fact, the depictions of black female bodies in popular culture debases and underestimates bodies of African American women. The black female is viewed continually as an inferior and dispensable sex object. In her essay, "Black Women: Shaping Feminist Theory," bell hooks(1994) points out that for a long time African American women and young girls were "daily beaten down, mentally, physically, and spiritually" and some of them still remain "powerless to change their condition in life" (p.270). Likewise, Frances Beale(1995) highlights the fact that black women, burdened by the traumatic experience of self-devaluation, are constantly "manipulated by the system, economically exploited, and physically assaulted" (p.146).
Morrison wants to elucidate that the beauty industry is adamant on associating black femininity with sensational eroticism and on associating African American women's sexuality with promiscuity. In the American culture, the stereotypes of the past as Collins (2004) state are "are revived by the disseminated images of the mass media" (p. 182); the image of a dark skinned young woman as a sensual black sex object as Wolf (1992) states "links a commodified 'beauty' directly and explicitly to sexuality," undermining "women's new and vulnerable sense of sexual self-worth"(p.11). The self-image of African American girls is greatly impacted by white American beauty ideals. Besides peer pressure, familial pressure which is also exercised upon them. The society urges women to adopt a certain image of female beauty. In the 1930s, black poor girls were flooded by portrayals of ideal beauty symbolized by white female actresses and by the standardized image of the popular Shirley Temple. By the 1990s beauty emerged as commodity; it composed a profitable product, which aided the American economy. The beauty industry based its financial profit on fashion supermodels who not only gained prevalent fame but also became the beauty icons of the decade. In God Help the Child, Morrison comments on these two time periods and demonstrates the ways the notion of beauty has influenced the live of some dark-skinned African American girls and affected their transition from girlhood to womanhood. Through the depiction of her fictional female character Bride, the author conveys that dark skin continues to influence the way young black girls view their femininity and that the misconception of ugliness attached to blackness continues to make the transition to womanhood a traumatic experience.

Paul Taylor (1999) states that ' [A] white dominated culture has racialized beauty, [in] that it has defined beauty per se in terms of white beauty, in terms of the physical features that the people we consider white are more likely to have'. Ramirez (2017) states that God Help the Child novel can be viewed partially as a modern day fairy tale which is portraying a reinterpretation of one of the tales of the Danish writer Hans Christian Anderson titled 'The Ugly 
Duckling'. This tale carries a powerful message of the importance of accepting self-image and valuing it. Henderson was rejected and bullied because of his gawky and strange physical appearance. His didactic tale is tailored to express and call for empathy and acceptance to the outcasts and those who are unfortunate. Morrison adopts the same technique in her novel but she uses the postcolonial discourse portraying African Americans especially African American women marginalized by the whitemale dominated societies.

Ramirez (2017) states that Toni Morrison fits into Helen Tiffin's(1987) definition of the postcolonial literatures and their colonizing endeavors as deconstructing, clarifying and unmasking the European domination as well as defining a rejected and denied self. Toni Morrison explores the destructive traumatic effects of Lula Ann's construction of beauty. Western ideals of beauty are the basis of her traumatized self- identity causing her feeling of inferiority and self -disgust. Lula Ann' s childhood skin as a child are the antithesis of what the white race regards beautiful which prevents her from sensing her worth and developing her ethnic pride and racial love. Pistelli (2015) states that Lula Ann even falsely accuses her teacher Sofia Huxley of molesting a child 'to get the attention of her mother, whose abuse takes the form of a far more insidious lovelessness.' Harris (1991) states that Colonized members of minority groups and victims of racism and bigotry are likely to turn themselves to victimizers embracing the central cultural paradigms which causes 'the breakdown of the bonds of human caring in the novel [which] reflects the general absence of ethics and morality' (p.38). Black Females absorbed the racial message the light skinned females are superior to dark skinned females, which became a widely known phenomenon called shadeism or colorism. This phenomenon affected the African American females negatively which made their own beauty and identity unacknowledged. Song (2012) states that one of the universal themes of "The Ugly Duckling" fairy tale as in other fairy tales is Transformation particularly the internal transformation which brings about the transformation of the outside world. Ramirez (2017) states that Bride dresses in white which addresses her submissiveness to Western beliefs about beauty and its materialistic values. Jensen (2013) states that in God Help the Child novel: “ Morrison's critical depiction of materialism and consumerism reveals the crucial role the product manufacturers and advertisers in a consumer society play as creators and enforcers of dominant beauty standards" (p.4). Ramirez (2017) states that in the fairy tale The Ugly Duckling by Henderson, Duckling finds his transformation into a swan his authentic identity as he is finally accepted among other animals and humans. Bride in God Help the Child is just connected to her physical appearance and material values which are considered superficial due to her adherence to imposed ideals of beauty. Jeri, the image consultant of Bride is a white American who says to Bride "You should always wear white, Bride. Only white and all white all the time' (Morrison 2015, p.33). Jeri added 'Not only because of your name'(Morrison 2015,p.33) after that he told her ' but because of what it does to your licorice skin' then he said "And black is the new black. Know what I mean? Wait. You're more Hershey's syrup than licorice. Makes people think of whipped cream and chocolate soufflé every time they see you" (P.33). What Jeri said made Bride laugh, she said ' Or Oreos?' ( Morrison 2015, p.33). Morrison emphasizes how Bride is commodified and sold as another beauty product. Bride whose "self-love is consistent with her cosmetic company milieu" (Morrison 2015, p.133).

But Bride does not mind to leave her cosmetic profession behind. She leaves for an identity journey to rural California to find her boyfriend to face him and question his rejection and abrupt departure.

'Which was the same as confronting herself, standing up for herself" (Morrison 2015, p.98).

Later Bride starts losing all the things that enslaved her to materialistic life like her car, her mobile phone, her clothes and so on. As Serpel (2015) writes that Bride undergoes a metaphorical death and loses her material and emotional comforts. Hence, her trip to California symbolizes her adherence to what is necessary and vital in her life. After her accident in the forest and in the middle of the scary night, Bride 
senses ' World-hurt- an awareness of malign forces changing her from a courageous adventurer into a fugitive' (Morrison 2015, p.83).

Ramirez (2017) states that when Booker knows that Bride visited a child molester and brings her presents, he rebuffs her and tells her that she is not the woman he wants. Booker's spiteful words invigorates Bride and she sinks into an identity crisis, feeling "Dismissed" and "Erased" (Morrison 2015, p.38), which Morrison represents by the presenting elements of magical realism. Bride 'experiences' a physical reversal "back into a scared little black girl" (Morrison 2015, p.142), 'losing' her femininity. Her transformation is portrayed through going through supernatural circumstances: the disappearance of her pubic and underarm hair, her ear piercings and her breasts. Her period stops and she even shrinks to the size of a child. And yet Scholes (2015) states that: "No one else appears to notice these changes. Whether they are real or simply the product of Bride's own imagination, it's impossible to tell; but the symbolism is clear: she is unable to escape her past and she can't escape her body". Morrison narrates:

After weeks of bird-washing Bride sank into the water with gratitude, prolonging the soaping until the water had cooled completely. It was when she stood to dry herself that she discovered that her chest was flat. Completely flat, with only the nipples to prove it was not her back. Her shock was so great she plopped back down into the dirty water, holding the towel over her chest like a shield (p.92).

The deconstruction of her femininity parallels Bride's journey of self-discovery, which leads to the eventual construction of her true womanhood through love and pregnancy. In God Help the Child novel, Bride's materialism is contrasted with the hippy couples' idealism. The couple Evelyn and Steve receive Bride after the car accident warmly and she realizes that all the people whom she thought loved her had scorned her and rejected her. Bride's concocted "hollywoody, teenager" name is in sharp opposite to the simplicity and hippy life of Evelyn and Steve. Bride wonders "Did she know anyway about good for its own sake, or love without things?" (Morrison 2015: p.92).
God Help the Child, in its similarity with the Ugly Duckling fairy tale, includes a conventional fairy-tale theme, unhappy childhood and abuse. From the very beginning, the gray duckling is rejected by everyone around him because he is distinct, too 'ugly' which equals an abuse experience. As Margaret F. Brinig and F. H. Buckley (1999) claim:

The story of the Ugly Duckling [...] masks the tragedy of children who suffer abuse [...]. More troubling is the evidence that 'different' children are more likely to be subjected to repeated abuse by parents or guardians [...] [Duckling] is rejected by his mother, rebuffed by his brothers and sisters, picked on by the other ducks in the barnyard, and scorned by other animals (p. 41).

The experience of Lula Ann and her mother's ill treatment of her due to her color and the perceived racist codes that affect Lula Ann's life is similar to the experience of the Ugly Duckling. Jonathan Sturgeon (2015) argues that when Bride's pubic hair disappears and her period stops, she is affected psychologically by racial rejection. He states that two events are less surrealist indications than indications of psychosomatic aggression affecting the body due to racial rejection.

Ramirez (2017) states that Bride in her epiphany away from her glamorous life realizes the destructive side of materialism and how materialism cannot replace her traumatic childhood. In The Ugly Duckling tale, Cat and Hen tell Duckling what to do to fit in. Duckling decides to go away and he survives a cold winter alone and is finally rescued by a peasant. Ramirez (2017) states that Bride finds her selffulfillment through the forest which represents her inner self. When the little emerald eyed girl Rain, finds Bride at the time of her car accident Bride likens her to Lewis Carol's constantly grinning cat. Rain watches how Steve rescues Bride in total awe with her mouth open. She also appears and disappears as if she is in a fantastical world. The Cheshire Cat is the only character that understands Alice(Bride). Rain confesses to the blue-black woman about her traumatic childhood at the hands of her mother. Her story demonstrates that the world is reigned by nonsense as in what happens in Alice in Wonderland story which is the same with what trauma causes in the lives of the people affected. 
While the curious Alice attempts to find what a fulfilling life looks like. Morrison attempts to devaluate the myth of beauty, emphasizing the fact that being beautiful is not enough, and that sticking to materialist values is unhealthy and self-destructive. hooks (1992) states that: 'It is only as we collectively change the way we look at ourselves and the world that we can change how we are seen. In this process, we seek to create a world where everyone can look at blackness, and black people, with new eyes' ( p.6). Morrison wants to shed light on the postblack or new-black term which leads also to term post racial blackness, all referring to the efforts to neutralize the expression "negro" to "black" to gain pride and self- regard. According to Taylor (2016), to be post black is to be affected by the fluidity of black identity by wrestling with how to orient oneself according to the norms of a wider society.

\section{Morrison's Black Maternal Figures and their Adoption of B eauty Standards}

It is worth to be noted that not only white racist Americans are considered responsible for the traumatized black female psyches, damaged lives, and distorted mindsets, but also those members of the African American society, who have held the sexist ideology and the white beauty myth. African American female novelists aspire to accentuate the effects of shadeism which maintains its hold on white American society and on African American communities, and continues to cause psychological harm.

The role of the mother is extremely influential when it comes to African American girls' development of character and their shift from girlhood years to womanhood. Inevitably, black mothers stand as the most supportive female figures with whom young black girls can identify. Because mothers represent models of womanhood, daughters unconsciously follow their opinions without questioning them. Therefore, African American mothers can be held accountable when they unconsciously support the stereotypical image of the ugly and repulsive black girl, as it has been constructed and imposed by white American culture. When Bride was born, her mother felt shocked due to her very dark bluish skin. Sweetness says:
It didn't take more than an hour after they pulled her out from between my legs to realize something was wrong. Really wrong. She was so black she scared me. Midnight black, Sudanese black. I'm light-skinned, with good hair, what we call high yellow, and so is Lula Ann's father. Ain't nobody in my family anywhere near that color. Tar is the closest I can think of yet her hair don't go with the skin. It's different-straight but curly like those naked tribes in Australia. You might think she's a throwback, but throwback to what? You should've seen my grandmother; she passed for white and never said another word to any one of her children (Morrison 2015, p.3).

Harris (2001) states that By maintaining the white beauty standards, black maternal figures leave themselves and their female children exposed to the institutionalized "white power" and seem to have little resistance against the stereotypical representation of "black female bodies in American popular imagination" (p.2). Devoid of its beauty, blackness becomes a burden especially in the eyes of mulatto mothers. As a result, those black mothers who teach their black-skinned daughters to embrace their inferior position in society and see themselves as symbols of ugliness can be held accountable for charging their children with feelings of self-hatred.

Lula Ann's mother lives according to the imposed ideals of the white racist society. This black woman lives by the white standards and views black skin color as a curse. Sweetness says:

Some of you probably think it's a bad thing to group ourselves according to skin color-the lighter, the better-in social clubs, neighborhoods, churches, sororities, even colored schools. But how else can you avoid being spit on in a drugstore, shoving elbows at the bus stop, walking in the gutter to let whites have the whole sidewalk, charged a nickel at the grocer's for a paper bag that's free to white shoppers? Let alone the name calling (Morrison 2015, p.4).

This is the reason why her daughter feels inferior and is deprived of maternal affection. From the very beginning of the novel, Sweetness is introduced to the readers, who recites her side of the story. Lula Ann's coming to the world is 
an unfortunate occasion for this mulatto mother. Lula Ann's skin is so black it petrifies her. Sweetness rejects her responsibility for Lula Ann's skin color, which she describes as "[m]idnight black," "[s]udanese black" (3). In particular, Sweetness, a light-skinned woman "with good hair" (Morrison 2015, p.3) compares herself to her daughter's physical appearance and blue-black skin, and concludes that her baby resembles "those naked tribes in Australia" because Lula Ann has "straight but curly hair" (Morrison 2015, p.3). In this way, Sweetness remotes herself from Lula Ann by specifying all the bodily differences that distinguish them from each other. Sweetness adheres to the ideals of the dominant white culture when she admits that skin color is a means of dividing individuals into groups; "the lighter [the skin color] the better" (Morrison 2015, p.4). Sweetness expresses her fears of name-calling, but also believes that light-skinned blacks who can pass as whites avoid "being spit in a drugstore, shoving elbows at the bus stop, walking in the gutter to let whites have the whole sidewalk, charged a nickel at the grocer's for a paper bag that's free to white shoppers" (Morrison 2015, p.4). Sweetness confesses that Lula Ann embarrasses her. The destructiveness of white American beauty standards is highlighted when, right after her daughter's birth, Sweetness tries to kill her baby girl by holding "a blanket over her face and press[ing]" (Morrison 2015, p.5). She even thinks "of giving her away to an orphanage someplace" (Morrison 2015, p.5). Abandoned by her husband due to "that terrible color" (Morrison 2015, p. 5) with which their child was born, Sweetness turns against Lula Ann, viewing her as a stranger and an enemy.

Alarmed by the inferior position submitted to black children like Lula Ann by white American society, Sweetness manages to discipline her daughter and teach her "how to behave, how to keep her head down and not to make trouble" (Morrison 2015: p. 7). Her submission and awareness of American racism and prejudice and "of skin privileges" ( Morrison 2015, p. 43), shapes Sweetness' attitude toward the child. The mother believes that she protects Lula Ann, because as she says, the child "didn't know the world" (Morrison 2015, p.41). She begins practicing what she believes is necessary by pressuring Lula Ann to call her 'Sweetness' instead of 'Mother' or 'Mama' (p.6), so that she would not be linked with her dark skin color in public. Also, she continuously asserts that Lula Ann's blackness is not her fault. Even if Lula Ann decides to change her name several times, Sweetness is convinced that her "color is a cross she will always carry"(Morrison 2015, p. 7). Consequently, Lula Ann tries to win her mother's affection and acceptance by holding a white American teacher accountable for child abuse. Lula Ann wants to gain feelings of worthiness that she is deprived of and make her mother proud. Lula Ann gives a false testimony to satisfy her mother. Throughout the novel Morrison narrates how Lula Ann explains that being touched and caressed by her mother is needed and crucial for her wellbeing. Unfortunately, Sweetness refuses to touch her daughter and feels frustrated when she has to give her a bath. Being submissive to the ideology of colorism, Sweetness shows no interest in caring for her daughter. The child's dark skin repels this mulatto mother from embracing or kissing her child. Although Morrison places Lula Ann's birth in the 1990s, she aims to imply that the imposed dominant beauty standards still influence the consciousness of African American mothers and have an impact on the mother-daughter relationship. Sweetness justifies the ill treatment of her daughter Lula Ann and says:

But you have to understand: I had to protect her. She didn't know the world. There was no point in being tough or sassy even when you were right. Not in a world where you could be sent to a juvenile lockup for talking back or fighting in school, a world where you'd be the last one hired and the first one fired. She couldn't know any of that or how her black skin would scare white people or make them laugh and trick her. I once saw a girl nowhere near as dark as Lula Ann and who couldn't be more than ten years old tripped by one of a group of white boys and when she fell and tried to scramble up another one put his foot on her behind and knocked her flat again (Morrison 2015, p.41).

At the end of the novel, Bride undergoes a transformation and she finds out that she is pregnant from her boyfriend, Booker. The child presents a new life and a new hope that matches 
the state that Bride reached eventually. Morrison narrates " A child. New life. Immune to evil or illness, protected from kidnap, beating, rape, racism, insult, hurt, self-loathing, abandonment. Error-free. All goodness. Minus wrath. So they believe" (Morrison 2015, p.175).

\section{Conclusion}

In God Help the Child, there are many traumatic experiences that affects the protagonist, Lula Ann. Racial trauma and parental trauma are the key traumas that face the protagonist in the novel. Lula Ann, the protagonist faces many unfavorable traumatic incidents because of her skin color and identity which is due to the injustice directed to the African American community in United States which is portrayed through the experience of her mother's treatment of her. Lula Ann realizes that she should not be commodified and continues her life devoid of her mother's influence and racial influences. Lula Ann's identity transforms by refusing to accept the racist stereotypes and by accepting her own identity which enables her to continue her life with hope and courage. Racial trauma causes many upheavals and challenges to the female African American identity which is portrayed in Toni Morrison's novel. Morrison diagnoses the symptoms of racial trauma through the novel and presents the possibility of healing through hope.

\section{References}

1. American Psychiatric Association. (2000) Diagnostic and statistical manual of mental disorders (4th ed.,text (18th ed.). Washington, DC, American Psychiatric Association.

2. Andersen, H. C. (1909-14) The Ugly Duckling. Harvard, The Harvard Classics, 17 April.<http://www.bartleby.com/17/3/1.html> (Accessed May 3 2019).

3. Beale, F. (1995) "Double Jeopardy: To Be Black and Female." Words of Fire: An Anthology of African-American Feminist Thought. Ed. Beverly Guy-Sheftall. New York,The New Press. 146-55. Print.

4. Breuer J. Freud S. Studies on hysteria (18931895). SE 2. London, Hogarth Press. 1966: 19305.
5. Brinig, M. F. \& Buckley F. H. (1999) Parental Rights and the Ugly Duckling. Scholarly Works: 41-65.

6. Caruth, C. (1996). Unclaimed experience: trauma, narrative, and history. Baltimore, Johns Hopkins University Press.

7. Carter, T. (2012) Measuring Race-Based Traumatic Stress Injury: Clinical and Research Instruments. APA Annual Convention, Vancouver, British Columbia, Canada,May 3-6.

8. Collins, Patricia Hill. (1991) Black Feminist Thought: Knowledge, Consciousness and the Politics of Empowerment. New York: Routledge.

9. Davis, C. (1999) "Self, Society, and Myth in Toni Morrison's Fiction." Modern Critical Views:Toni Morrison. Ed. Harold Bloom. Philadelphia,Chelsea House . 7-25. Print.

10. DuBois, W.E.B.(1903) The Souls of Black Folk. A.C. McClurg\&Co.,Chicago.

11. Duvall, J.(2000) The Identifying Fictions of Toni Morrison (Modernist Authenticity and Postmodern Blackness.

12. Erichsen, J.E.(1867) On Railway and Other Injuries of the Nervous System. Philadelphia, Henry C. Lea.

13. Erikson,K. (1995) "Notes on Trauma and Community."Caruth, Trauma 183-99.

14. Equiano, O.(1814) The Interesting Narrative of the Life of Olaudah Equiano, or Gustavus Vassa. the African, London.

15. Fragkouli,K. (2017) Skin Color Politics and the Beauty Standard: Examining African American Girlhood in Toni Morrison's The Bluest Eye (1970) and God Help the Child (2015). Aristotle University of Thessaloniki.

16. Freud, S., \& Hutchins, R. M.(1952) The major works of Sigmund Freud. Chicago, W. Benton.

17. Freud, S. \&James S.(1989) Beyond the Pleasure Principle. Norton. Goulimari, P. (2011) Toni Morrison. Routledge: New York.

18. Gross, T. (2015) "I Regret Everything':Toni Morrison Looks Back On Her Personal Life". Fresh Air. August 24, 2015. http://www.npr.org...

19. Harris, T. (2001) Saints, Sinners, Saviors: Strong Black Women in African American Literature. New York, Palgrave. Print.

20. Herman, J. L. (1997) Trauma and recovery: the aftermath of violence--from domestic abuse to political terror. New York, BasicBooks.

21. hooks, b. (1992) Black Looks: Race and Representation. Boston,South End. 
22. Jensen, K. (2013) Toni Morrison's Depiction of Beauty Standards in Relation to Class,Politics of Respectability, and Consumerism in Song of Solomon. University of NewOrleans Theses and Dissertations. Paper 1743.

23. Kubistchek, M. D. (1998) Toni Morrison: a critical companion. Westport, Conn, Greenwood Press.

24. Kotecki, G. (2013)“The Ghost Daughter Returns Home: Memory of Slavery in Toni Morrison's Beloved." Sociology Study, vol. 3, no. 12 , pp. 933-940.

25. Leys, R.(2000) Trauma: A Genealogy. Chicago, The University of Chicago Press.

26. Massey, D. S.,\& Denton,N. A. Denton. American Apartheid: Segregation and the Making of the Underclass. Cambridge: Harvard UP, 1993. Print.

27. Myers, G. (1989). The New Historicism in Literary Study. Spring-Verlag. Academic Questions 2:27. http://doi.org/10.1007/BF02682779[Accessed 12th of June 2019].

28. McKay,N.(1988) Critical Essays on Toni Morrison(Critical Essays on American Literature).Twayne Publishers.

29. Morrison , T. (n.d.). Unspeakable Things Unspoken: The Afro-American Presence in American Literature. Ann Arbor,: University of Michigan. http://hdl.handle.net/2027/spo.act2080.0028.001.

30. Morrison,T. (1993) The Art of Fiction No.134 Interviewed by Elissa Schappell for The Paris Review.

31. Morrison,T. (2015) God Help the Child. London: Vintage. Print.

32. Morris on, T. (2015) "Toni Morris on on her New Novel God Help the Child, Race and Racism" Interviewed by Carol Off For CBC Radio: As It Happens. http://www.cbc.ca.

33. Ramirez,M. L. (2017) Radicalized Beauty: 'The Ugly Duckling' in Toni Morrison's God Help the Child. Complutense Journal of English Studies.

34. Rich, Adrienne. (1976) Of Women BornMotherhood as Experience and Institution. NewYork: w.w.w Norton \& Company.
35. Scholes, L. (2015) Toni Morrison's God Help the Child. BBC Culture, 21 April.<http://www.bbc.com/culture/story/201504 21-review-toni-morris ons-new-novel $>$ (Accessed May 7 2019).

36. Serpell, C. N. (2015) 'God Help the Child,' by Toni Morrison. SFGATE, 28 May.<http://www.sfgate.com/books/article/GodHelp-the-Child-by-Toni-Morris on-6202725.php> (Accessed July 18 2015).

37. Song, C. S. (2012) In the Beginning Were Stories, Not Texts: Story Theology. Cambridge,UK: Casemate Publishers.

38. Stamm, H. (1996) Measurement of Stress, Trauma, and Adaptation. Sidran, 1996.

39. Taylor, P. C. (2016) Black Is Beautiful: A Philosophy of Black Aesthetics.Pondicherry,Wiley-Blackwell. Digital.

40. Tiffin, H. (1988) Post-Colonialism, PostModernism and the Rehabilitation of PostColonial History. Journal of Commonwealth Literature 23.1: 169-81.

41. Toure. (2001) Who is Afraid of Post-blackness: What It Means to Be Black Now. New York, The Free Press. Print.

42. Van der Kolk, B. (2014) The body keeps the score: Brain, mind, and body in the healing of trauma. New York: Viking.

43. Wiegman, R. (1995) American Anatomies: Theorizing Race and Gender. London, Duke UP. Print.

44. Wolf, N. (1992) The Beauty Myth: How Images of Beauty Are Used Against Women. New York, Anchor Books. Print.

45. Yoshinobu, H.(2001) Richard Wright, Toni Morrison, and the African "Primal Outlook Upon Life". Southern Quarterly 40(1),139-53.Retrieved from http://Digital commons.kent.edu/engbub/8 [Accessed 15th of July 2019] 